\title{
ADDITIONAL EVIDENCE OF THE HOLOCENE TRANSGRESSION IN LAKE LADOGA ON THE BASIS OF AN INVESTIGATION OF THE BEACH DEPOSITS ON THE ISLAND OF MANTSINSAARI
}

\author{
IRINA DELUSIN and JOAKIM DONNER
}

\begin{abstract}
DELUSIN, IRINA and DONNER, JOAKIM, 1995. Additional evidence of the Holocene transgression in Lake Ladoga on the basis of an investigation of the beach deposits on the island of Mantsinsaari. Bull. Geol. Soc. Finland 67, Part II, 39-50.

On the basis of a study of peats covered by a beach ridge on the island of Mantsinsaari in Lake Ladoga, the beginning of the Ladoga transgression here was dated at $2980 \pm 80$ radiocarbon years B.P. Similar dates have been obtained from the southern shores of the lake. They show that the transgression reached its maximum in the whole lake at the same time and that the River Neva was formed between about 2900 and 2500 B.P. There is no evidence in the sections studied on the island of Mantsinsaari of two stages in the Ladoga transgression during the Holocene. But the formation of the River Vuoksi dated at 5200 B.P. on the basis of ages from the bog Linnansuo in Imatra and the Lake Saimaa area probably accelerated the transgression.
\end{abstract}

Key words: paleolimnology, lakes, transgression, beach ridges, peat pollen analysis, absolute age, C-14, Holocene, Mantsinsaari, Lake Lagoda, Russia.

Irina Delusin: St. Petersburg Branch of the Institute of Oceanology, Russian Academy of Sciences, I Linija 30, St. Petersburg 199053, Russia.

Joakim Donner: Department of Geology, P.O. Box 11, FIN-00014, University of Helsinki, Finland.

\section{INTRODUCTION}

In the study of the postglacial history of Lake Ladoga the nature and age of its transgressions has been one of the most important problems. This subject has been dealt with by several authors, starting with Ailio (1898). Two transgressions took place after the deglaciation, first the transgression in Ancylus time, and later on the second and biggest that has been named the Ladoga transgression. The reason for and age of the Ladoga transgression has up to now, however, been debatable. The gist of this discussion was given in the book by Malachovskij et al. (1993), which 
covers the question of the age of the beginning of the transgression and how it can be traced on the shores of the lake (see also Koshechkin and Ekman, 1993). In the investigation of the transgression it is not easy to find suitable sites for dating it and many of the results are contradictory. In the present study of the water level changes in Lake Ladoga the beach ridge on the island of Mantsinsaari was chosen. Its formation was governed only by the fluctuations of the level of Lake Ladoga, without any influence of rivers on the sedimentation. Nor have there been any great changes caused by wind action.

The coastal features on the island of Mantsinsaari were described for the first time by Ailio (1898). According to his preliminary estimate the oldest beach ridge on the island was formed at the time of the Litorina Sea. This implied that during the Litorina transgression of the Baltic Sea, the level of Lake Ladoga also rose. Later Ailio (1915), after new investigations, concluded that the formation of the beach ridge relates to changes within Lake Ladoga itself rather than to the Litorina transgression. During the formation of the beach ridge the lake reached its maximum level, and as a result of this rise the Rive Neva in the southern part of Lake Ladoga was formed and the lake assumed its present shape. Ailio (1898) estimated that the altitude of the abrasion scarp on Mantsinsaari is at $21-21.5 \mathrm{~m}$.

Ailio analysed the macrofossil plant remains of the peat buried under the transgression deposits of the beach ridge. He first concluded that the peat was formed at the end of the Ancylus time (Ailio, 1898). Later on, however, he came to the conclusion that it is younger (Ailio, 1915). The method of pollen analysis was not known at the time of Ailio's investigations. Hyyppä (1943) reinvestigated the beach ridge on the island of Mantsinsaari, applying pollen analysis to the study of the buried peat. In order to check Ailio's evidence, Hyyppä made a profile along the drainage channel Kriishanoja crossing the beach ridge (Figs 2 and 3). The maximum altitude of the ridge is $20 \mathrm{~m}$ and its distal edge is at $17-18 \mathrm{~m}$ above sea level (a.s.1.). Hyyppä examined the deposits in three sections along the profile and collected a series of samples for pollen analysis. His results confirmed those of Ailio's. The beach ridge is built up of sand and well rounded pebbles. It is in places $50 \mathrm{~m}$ wide and $2 \mathrm{~m}$ high. The peat is covered by the beach deposits, but on the proximal side of the ridge the peat reaches the surface and merges into the bog Suursuo. Hyyppä concluded that the buried peat is from the Litorina time, as shown by a high percentage of pollen of deciduous trees, and that the beach ridge itself was formed in post-Litorina time. Furthermore, in analysing the diagrams, he came to the conclusion that the transgression overflowed the bog at exactly the end of the Litorina time and that it represents the maximum stage of the Ladoga transgression. Besides, Hyyppä analysed the diatoms in the sediments and found only fresh water forms, which also supported his conclusion. At the time of Hyyppä's investigation the age of the deposits at Kriishanoja could not be determined more precisely.

After the investigations by Ailio and Hyyppä numerous studies of the Holocene of Lake Ladoga as a whole have been undertaken, but the dating of the Ladoga transgression and the explanation of the reason for it have varied (Saarnisto, 1970; Saarnisto and Siiriäinen, 1970; Koshechkin and Ekman, 1993; Malachovskij et al., 1989, 1993). Malachovskij et al. (1993), in agreement with earlier work, concluded that the Ladoga transgression took place in one stage only (Ailio, 1915; Markov et al., 1934; Kvasov, 1978), and that it reached its maximum altitude at c. $3000-2800$ B.P. As a result of this, the River Neva was formed and after a rapid erosion of the new outlet the level of Lake Ladoga dropped here from $15 \mathrm{~m}$ to $5 \mathrm{~m}$, near to its present level. According to Koshechkin (1990) and Koshechkin and Ekman (1993), following the idea of a longterm transgression which started c. 5000 B.P., Lake Ladoga had a transgression in two stages. In a recent investigation by Malachovskij et al. (submitted for publication) the maximum stage of the Ladoga transgression at the southern coasts of the lake was dated as well as the formation of the River Neva. The reason for the transgression was not discussed in the above-mentioned papers, but has 


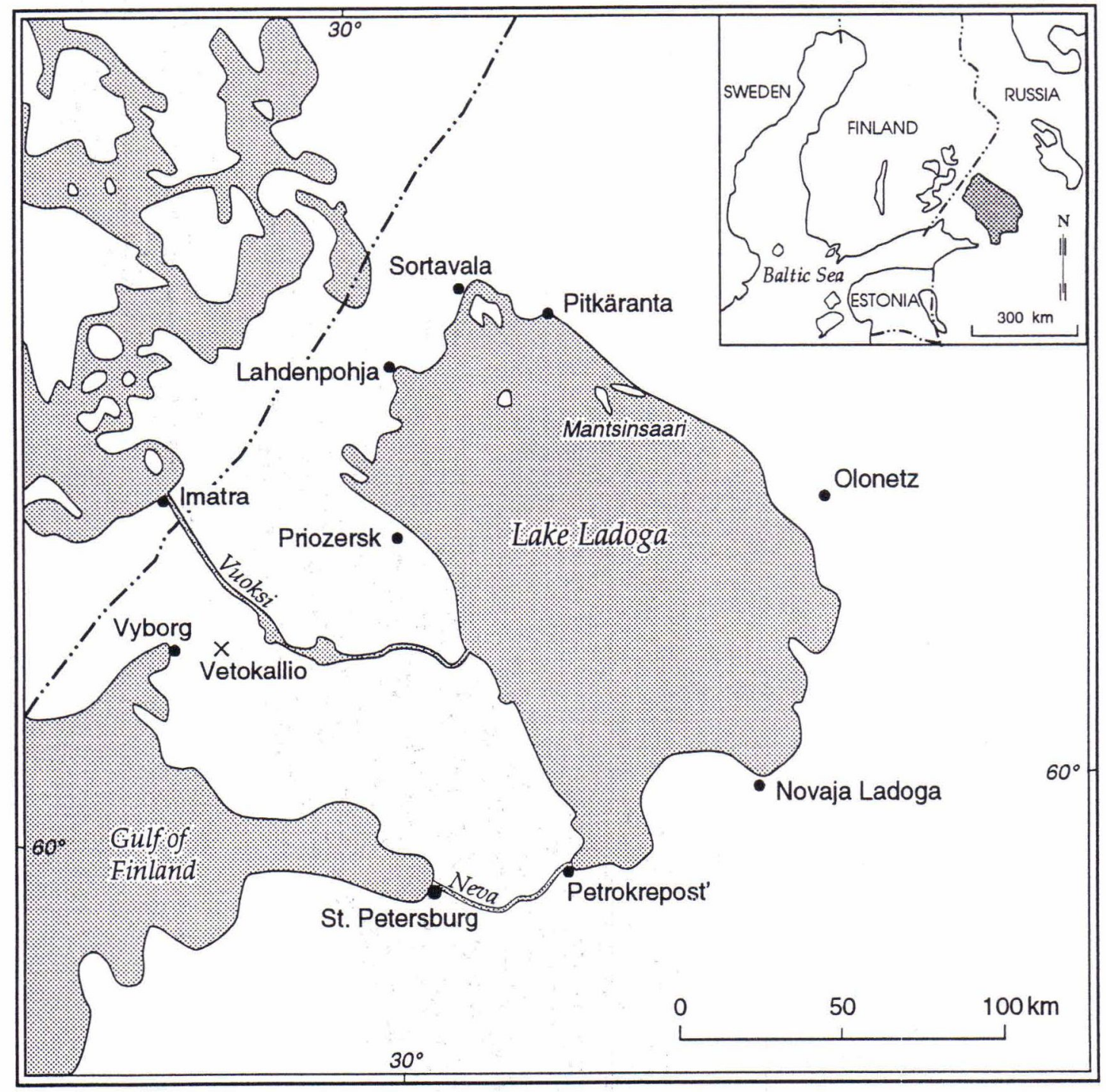

Fig. 1. Lake Ladoga and surrounding areas.

commonly been explained as having been caused by the glacio-isostatic uplift of the northern part of Lake Ladoga.

In the present investigation the peat at the site of the beach ridge at Kriishanoja on the island of Mantsinsaari studied by Hyyppä (1943) was reinvestigated, in order to obtain as exact a dating as possible of the Ladoga transgression. The samples for pollen analysis and radiocarbon dating were taken during an excursion of the Division of
Geology and Palaeontology of the Department of Geology, University of Helsinki, around Lake Ladoga in June 1993. In addition to the island of Mantsinsaari, samples were earlier, in the summer of 1992, collected from the bog Linnansuo in Imatra in south-eastern Finland, a bog flooded at the time of the formation of the River Vuoksi, when the waters of Lake Saimaa, as a result of a transgression, broke through the end moraine of Salpausselkä I to drain into Lake Ladoga. The site 


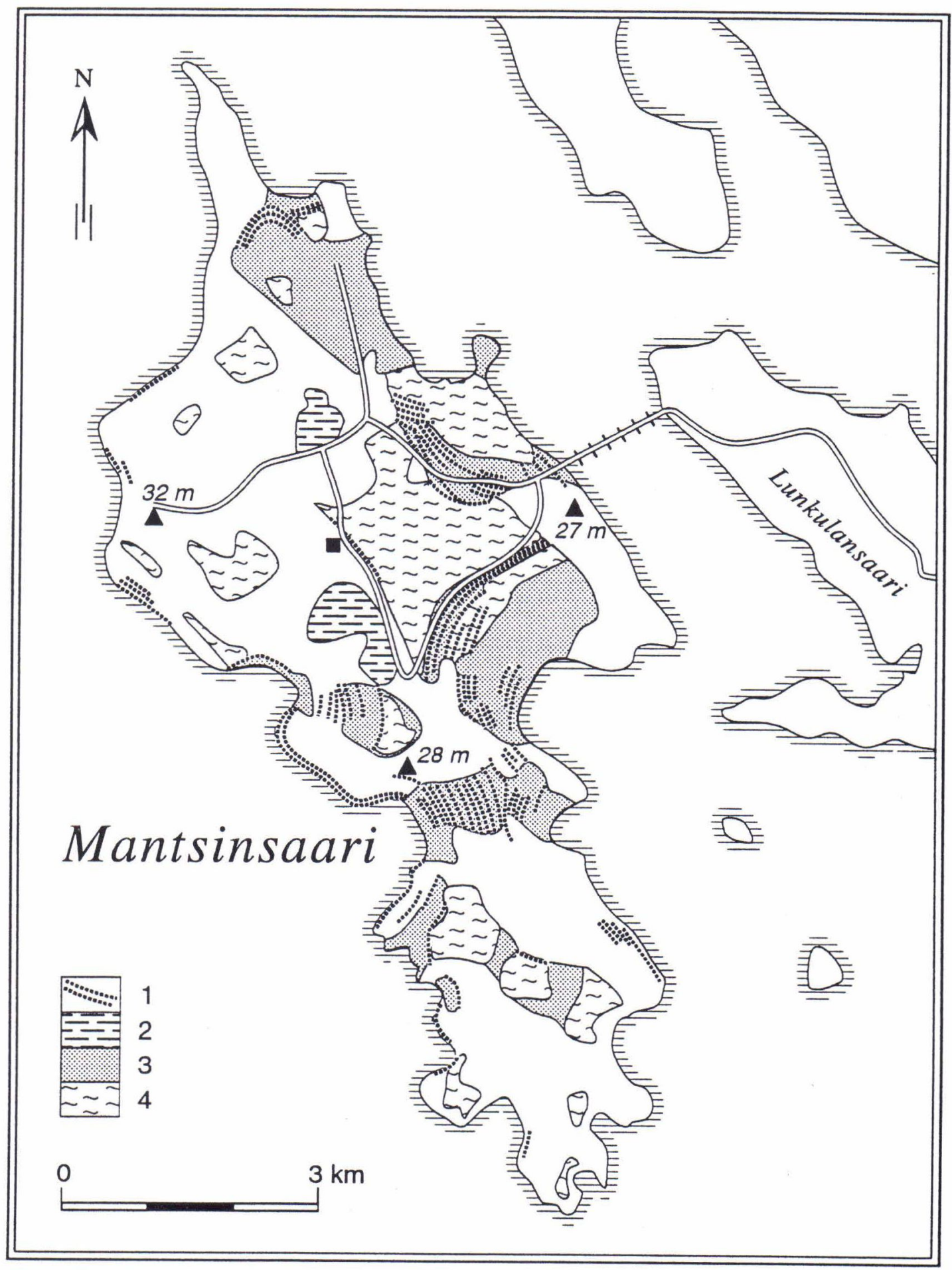

Fig. 2. The island of Mantsinsaari (after Ailio, 1898). 1, beach formation; 2, Holocene clay; 3, Holocene sand; 4, peat. Black square, Kriishanoja (site of section in Fig. 3). 
of Linnansuo was studied in order to evaluate the effect of the formation of the River Vuoksi on the Ladoga transgression. The drainage of Lake Saimaa has been considered to have had an accelerating effect on the transgression (Saarnisto and Siiriäinen, 1970; Taavitsainen et al., 1994).

The radiocarbon dating of the samples both from the island of Mantsinsaari and from Linnansuo was done in the Dating Laboratory of the University of Helsinki. All dates are given as conventional radiocarbon ages. In preparing the slides for pollen analysis the methods described by Faegri and Iversen (1989) were used. In the pollen diagrams the percentages of the tree and herb taxa were based on the sum of pollen of terrestrial plants, and those of spores also on the total pollen sum.

\section{THE ISLAND OF MANTSINSAARI}

The island of Mantsinsaari on the north-east coast of Lake Ladoga is c. $14 \mathrm{~km}$ long and $4 \mathrm{~km}$ wide (Fig. 1). It is on the whole low; only a few places reach an altitude of 21-22 $\mathrm{m}$ a.s.1. Mantsinsaari, together with the island of Lunkulansaari (Fig. 2), represent a continuation of a linear Precambrian ridge, as shown by the coastal relief. The coast forms here an archipelago with long islands and peninsulas, divided by narrow and deep straits. They are elongated in a south-east to northwesterly direction. The island of Mantsinsaari, as well as Valamo, the biggest island of Lake Ladoga, consist of diabase intrusions through Riphean formations with an age of c. 1150-1180 million years, later eroded during the Pleistocene by glaciers (Amantov, 1993).

The glaciations of the area have been described by many authors (Kvasov, 1990) who have shown that during the Pleistocene glaciers advanced several times over the Lake Ladoga basin, destroying previously deposited sediments. There are not many Pleistocene morphological features in the area except some washboard moraines. The island of Mantsinsaari was deglaciated about 11000 B.P. at the time of the Baltic Ice Lake and varved clays were deposited in the lower parts of the island. The younger Holocene deposits are mainly organic sediments of mires and covers of sand, in places on top of bogs. Some of the most conspicuous morphological features are the beach ridges. These ridges and sediments associated with them have been the main objects in the present investigation.

In the study of the island of Mantsinsaari two cores were collected close to the transect across the highest beach ridge at Kriishanoja studied by Hyyppä (1943), from his points 3 and 7, using a Russian peat sampler. The new cores, P5 and P52 (Fig. 3), were $1.20 \mathrm{~m}$ and $0.60 \mathrm{~m}$ long respectively. They were sampled in the field for pollen analysis at $2-5 \mathrm{~cm}$ intervals. Samples of peat from the depths of 45-50 cm (P5) and 65-75 $\mathrm{cm}$ (P5-2) were collected for radiocarbon dating.

The analysed sediments in core P5 from Mantsinsaari consist of a compressed peat covered

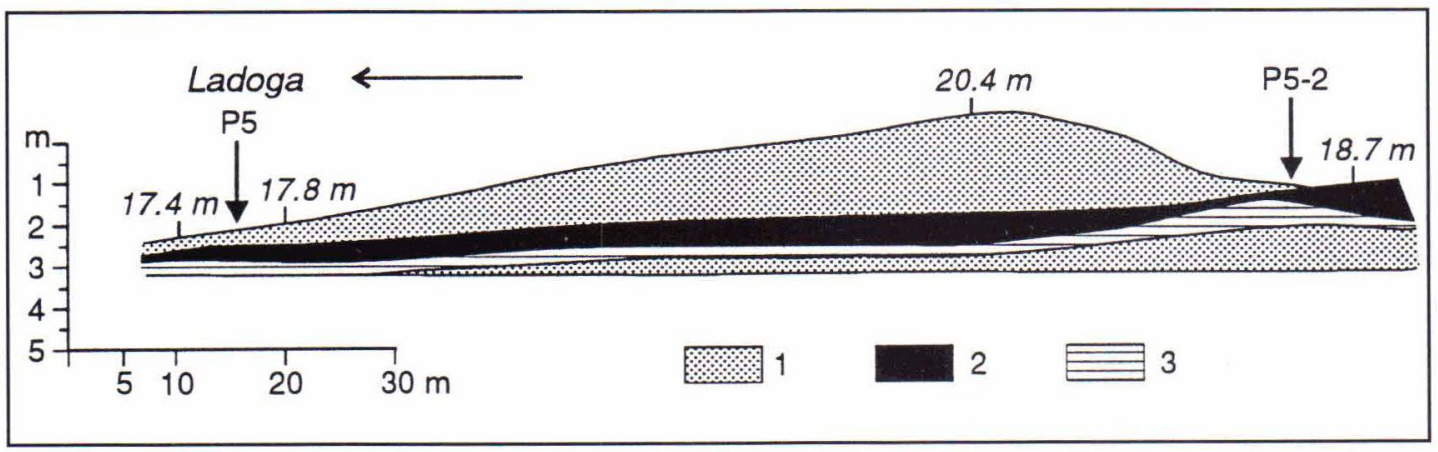

Fig. 3. Studied sections $P 5$ and P 5-2 on the island of Mantsinsaari (profile after Hyyppä, 1943, Fig. 3). 1, sand and gravel; 2 , peat; 3 , silty clay. 


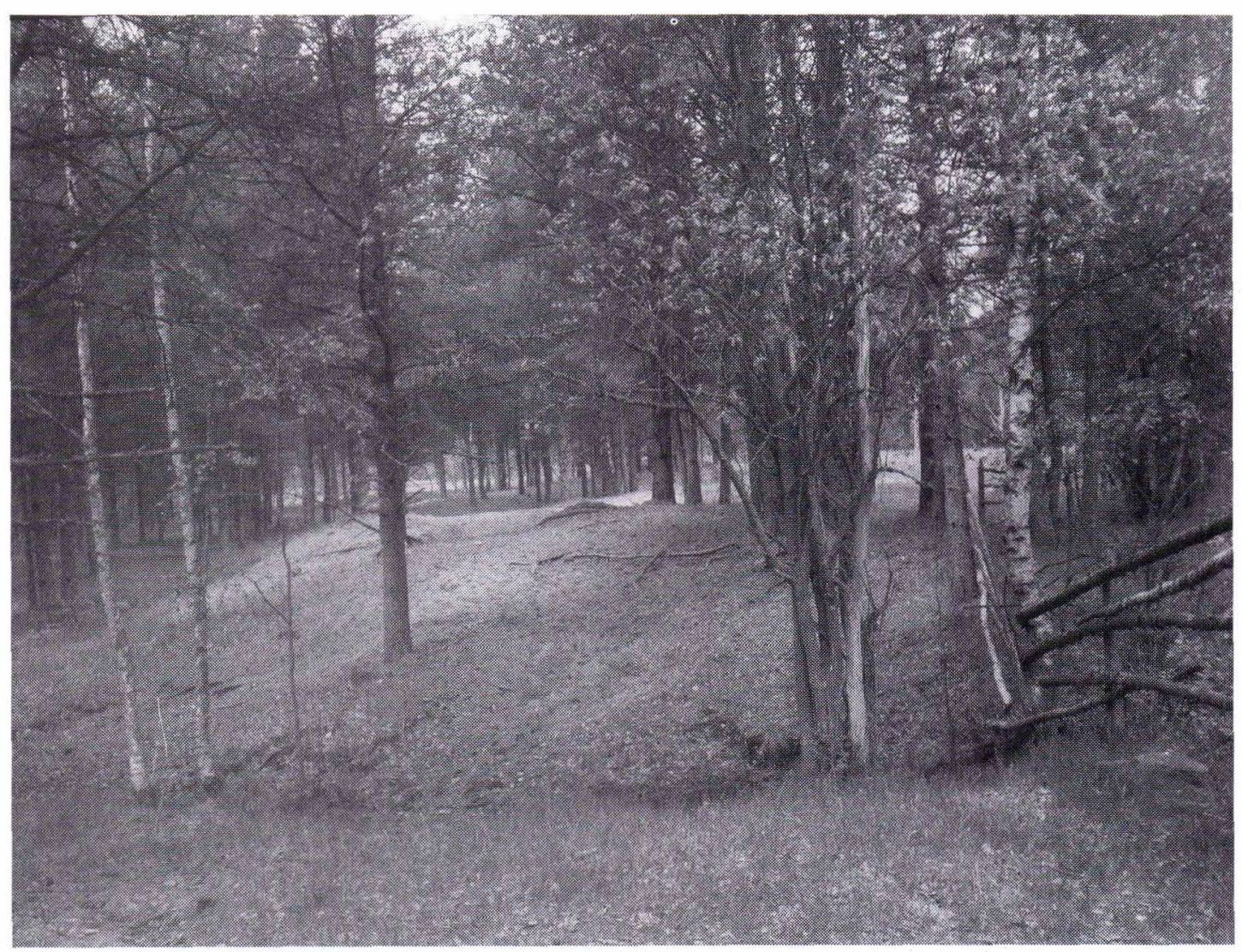

Fig. 4. Beach ridge on the island of Mantsinsaari at studied sections.

by a $5 \mathrm{~cm}$ thick layer of silty sand and $40 \mathrm{~cm}$ of sand with well rounded flat beach pebbles (Fig. 4). The sediments of the beach ridge accumulated during the transgression that covered the peat (Fig. 5 ). By comparing the tree pollen assemblages in the diagram of core P5 with those in diagrams from the area as a whole, the regional pollen assemblage zones (PAZ) proposed for Lake Ladoga by Delusin (1991) could be used (Fig. 6). The boundary between zones Va and Vb in the Subboreal chronozone is marked by an increase of Picea, whereas at the beginning of the Sub-atlantic chronozone VI the percentages of the deciduous trees of Corylus, Ulmus, Quercus and Tilia, typical for the Flandrian climatic optimum, decrease. The correlation of the zones represented in the P5 diagram with the chronozones is shown in Table
1. The radiocarbon age for the topmost layer of the peat underneath the sand is $2890 \pm 80$ (Hel3402). The dated horizon is in the pollen diagram below the lower boundary of the Sub-atlantic chronozone dated at $2.5 \mathrm{ka}$ and is thus in agreement with the division of the diagram. Even if the zonation of the pollen diagram is somewhat uncertain on the basis of the pollen composition of the beach sediments, the radiocarbon date shows that the transgression which formed the beach ridge reached its maximum on the island of Mantsinsaari after about 2900 B.P. A slight erosion of the peat during the transgression cannot be ruled out, which means that the radiocarbon age is a maximum age for the peak of the transgression.

The core P5-2 is from the edge of the bog on the lee-side of the beach ridge (Fig. 3), from the 
basal sediments. There is underneath the peat 10 $\mathrm{cm}$ of mud and lowermost $20 \mathrm{~cm}$ of grey clay. As the above-mentioned regional assemblage zones could not be used directly for the pollen diagram (Fig. 7), it was divided into the three local zones (LPAZ) Mt 1, Mt 2 and Mt 3 on the basis of both changes caused by the development of the bog, as the marked decrease in the Polypodium curve at the boundary between $\mathrm{Mt} 1$ and $\mathrm{Mt}$ 2, and changes of a more regional character, as the increase of Picea, Pinus and Corylus at the beginning of zone Mt 3. Because of these latter changes the zone boundary Mt 2 / Mt 3 was correlated with the AT / SB (IV / V) chronozone boundary (Table 1), whereas both Mt 1 and Mt 2 represent the Atlantic chronozone IV. The radiocarbon age of $5170 \pm 170$ (Hel-3401) supports the general correlation presented in Table 1. The age of the thin basal clay cannot be determined, but on the basis of the tree pollen composition in the pollen diagram the clay is, as concluded above, from the Atlantic period, younger than 8000 years. This means that the organic sediments in the bog were formed some time in the beginning of the Flandrian climatic optimum, at the time of the Atlantic chronozone IV, and that the peat here started to grow at about 5000 B.P. At the site for the P5 core the peat growth ceased when the Ladoga transgression covered the bog with the material of the beach



Fig. 5. Upper part of section P 5 in beach ridge on the island of Mantsinsaari, with peat underneath beach sand and gravel.

Table 1. Correlation between the chronozones with zones in the pollen diagrams from Mantsinsaari and Linnansuo (Imatra).

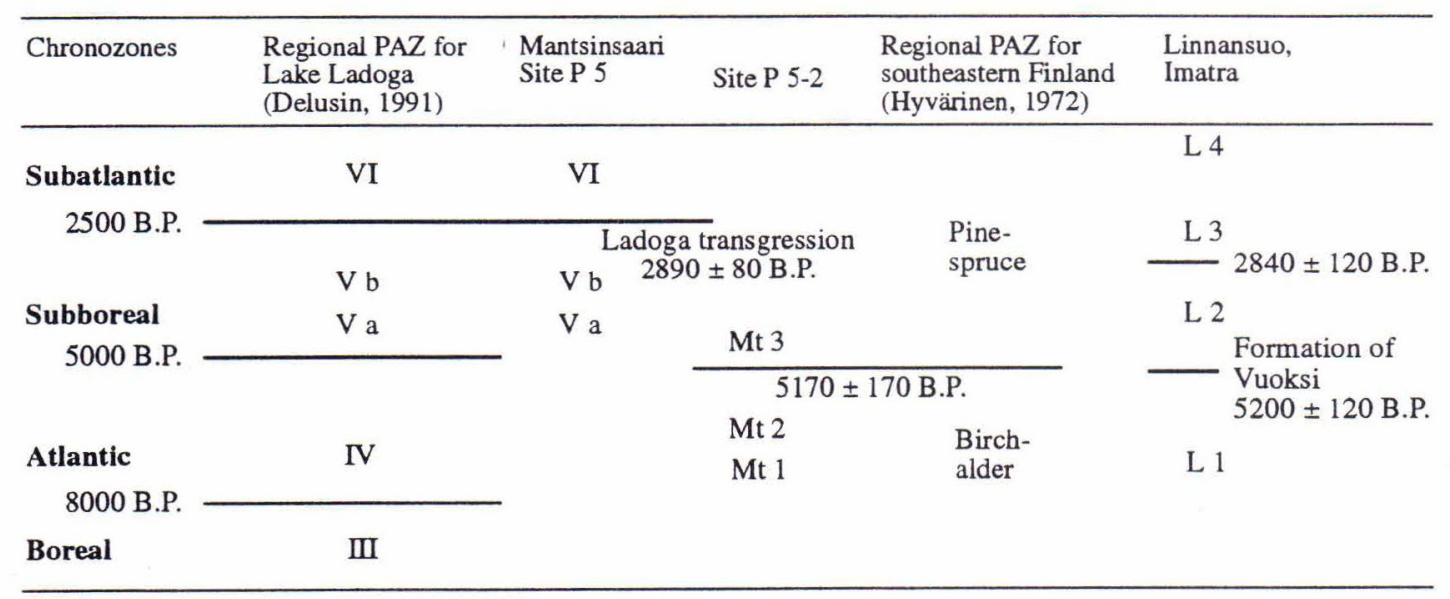




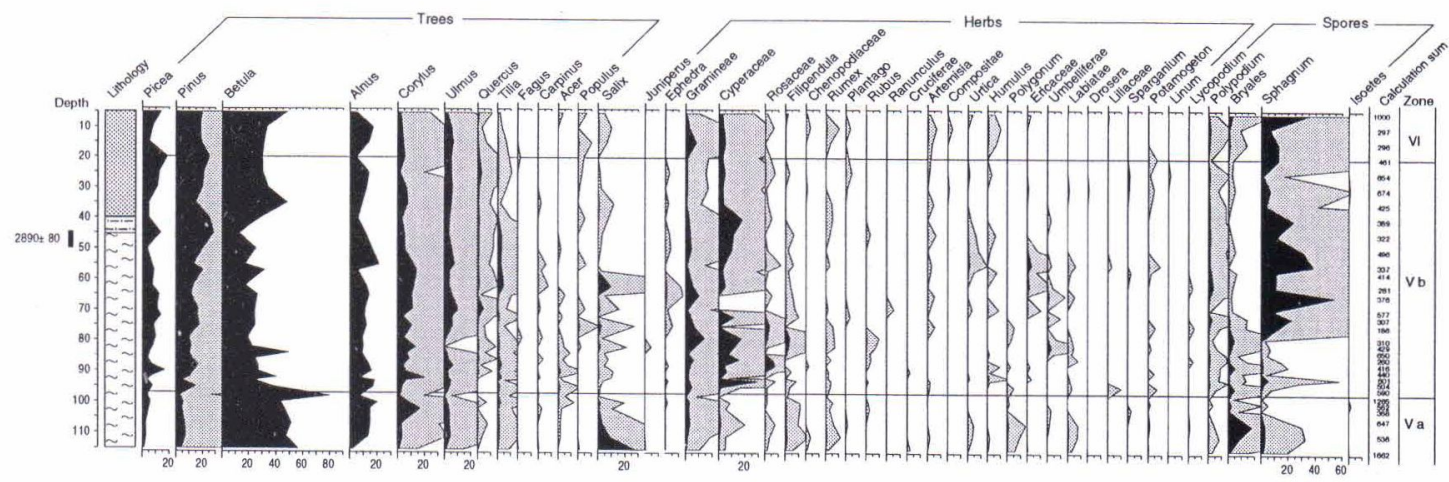

Fig. 6. Pollen diagram P 5 from Mantsinsaari. Stratigraphy from top to bottom: sand, silty sand and peat.

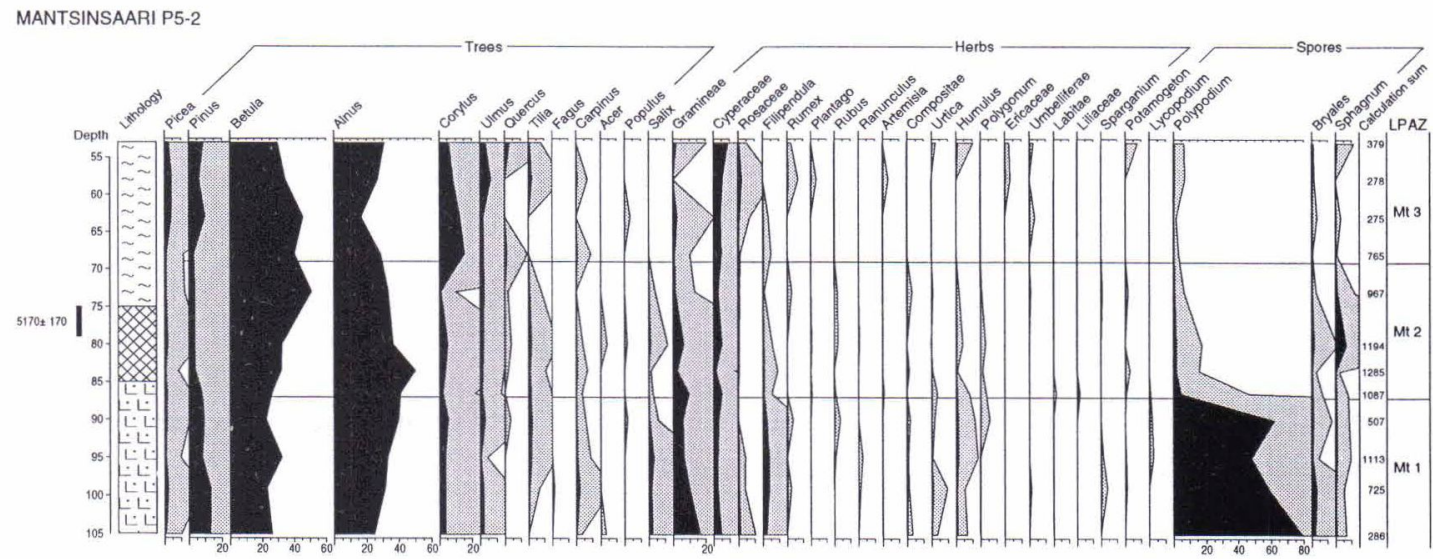

Fig. 7. Pollen diagram P 5-2 from Mantsinsaari. Stratigraphy from top to bottom: peat, mud and grey silty clay.

ridge. The peat types encountered at the Kriishanoja site were determined in detail by Hyyppä (1943) and given in his pollen diagrams.

\section{THE FORMATION OF THE RIVER VUOKSI}

As a result of the transgression in Lake Saimaa the River Vuoksi, starting at Vuoksenniska in Imatra (Fig. 1), was formed as an outlet into Lake Ladoga. The drainage of Lake Saimaa is stratigraphically well recorded in the bog Linnansuo $5 \mathrm{~km}$ south of Vuoksenniska, on the eastern side of the river. When it was formed its waters flooded the bog and deposited a thin layer of sand and silt on top of the bog, a layer thinning out and being only a few centimetres thick about $700 \mathrm{~m}$ from the river. After having been flooded for some time the peat growth continued on top of the sand and silt. Because of the clear stratigraphical changes near the surface in the bog of Linnansuo, it has provided a suitable site for dating the formation of the River Vuoksi. Hellaakoski (1936) and Lappalainen (1962) each published a pollen diagram of the bog Linnansuo, and later so did Saarnisto (1970), who also published two radiocarbon dates of wood fragments found immediately below the flood sediment.

In spite of the above-mentioned detailed investigations to date the formation of the River Vuoksi, a new pollen diagram was analysed of the 


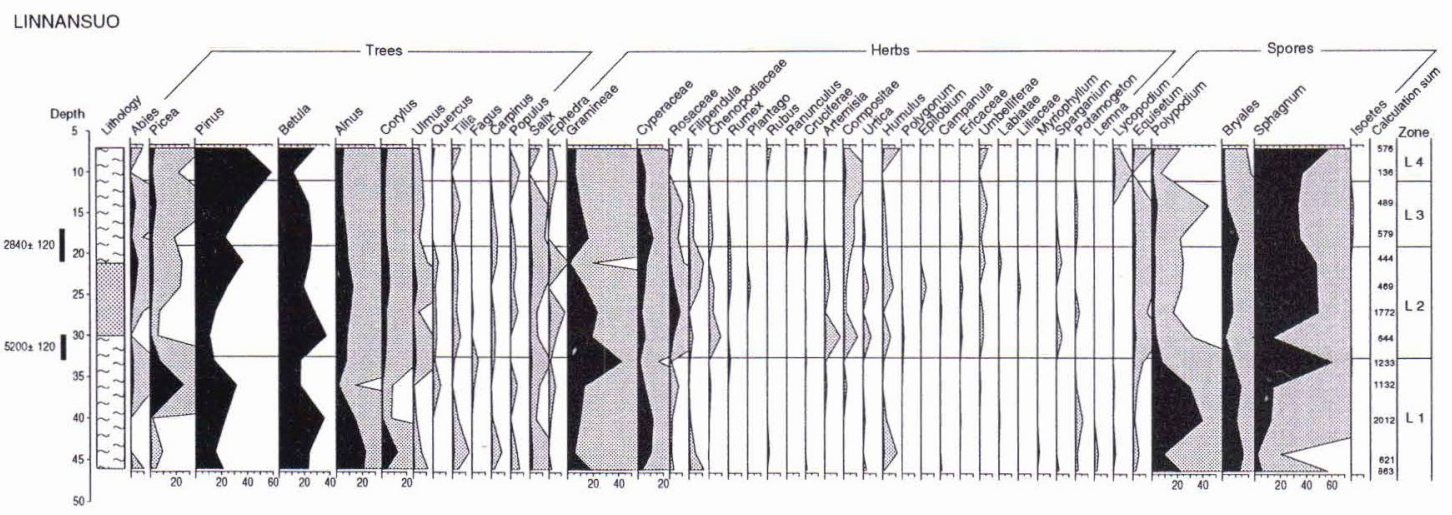

Fig. 8. Pollen diagram from the bog Linnansuo, Imatra. Stratigraphy from top to bottom: peat, sand and peat.

topmost sediments of the bog Linnansuo, the samples being from a section dug at a place where the sandy flood sediment is less than $10 \mathrm{~cm}$ thick (Fig. 8). The pollen diagram was divided into four local assemblage zones, $\mathrm{Li} 1$ - $\mathrm{Li}$ 4, which were then compared with the regional pollen assemblage zones for south-eastern Finland (Table 1), as divided by Hyvärinen (1972). Zone Li 1 corresponds to the upper part of the Birch-alder zone, and also to the upper part of the Atlantic chronozone, with its upper boundary at about 5000 B.P. (Hyvärinen, 1972). Zones L 2 and L 3 both correspond to Hyvärinen's Pine-spruce zone and were divided foremost on the basis of the rise in the Pinus curve, accompanied by a small rise in the Picea curve. As the percentages of many pollen taxa change near the top of the diagram, a fourth local assemblage zone, $\mathrm{Li} \mathrm{4}$, was separated in the Linnansuo diagram, also corresponding to Hyvärinen's Pine-spruce zone. It can be seen in Table 1 that the suggested correlation of the local zone boundaries $\mathrm{Li} 1$ / Li 2 and $\mathrm{Li} 2$ / Li 3 with the chronozones is supported by the two radiocarbon dates from the bog Linnansuo.

The pollen diagram for this bog shows some features that are not common in diagrams from the southern parts of Finland. Abies is represented in many of the spectra and also Carpinus, although it is less frequent. The latter has been recorded in younger Holocene diagrams in which the number of counted pollen is relatively high, but Abies has seldom been recorded; in a diagram from Vakojärvi
(Donner, 1972) north-west of Helsinki there were a few occurrences in the upper part of the diagram, together with Fagus, also present in the Linnansuo diagram. The low frequencies of pollen of these taxa common in diagrams from further south in Central Europe, must be considered to be the result of long-distance transport. Because of it being at a relatively high altitude, the bog of Linnansuo is suitably exposed to receive pollen transported from afar, more so than mires in more protected places.

The radiocarbon age of the peat immediately below the sediment formed in the bog Linnansuo, at the time when it was flooded as a result of the formation of the River Vuoksi, is $5200 \pm 120$ (Hel3235). As there is no indication of erosion of the underlying peat the age gives an accurate date for the formation of the river and for the shoreline in the Saimaa lake complex from the time of its maximum position before the lake was drained. The radiocarbon age of $2840 \pm 120$ (Hel-3254) of the peat on top of the flood sediment of Linnansuo merely dates the time when the peat growth, interrupted by the flood, again started at the sampled site and is not related to the flood.

The age of 5200 B.P. given here for the formation of the River Vuoksi agrees essentially with that given by Saarnisto (1970), who concluded it to be "about 5000 B.P. or slightly over". Saarnisto obtained two radiocarbon ages for wood fragments from underneath the flood sediment in the bog Linnansuo, both ages being 5200 B.P. 
Table 2. Radiocarbon ages used for dating the formation of the River Vuoksi.

\begin{tabular}{|lll|}
\hline Linnansuo, peat & Hel-3253 & $5200 \pm 120$ B.P. \\
Saarnisto (1970): & & \\
Linnansuo, wood & Hel-8 & $5200 \pm 140$ B.P. \\
Linnansuo, wood & P-1542 & $5183 \pm 50$ B.P. \\
Immolanlampi, sandy mud & Hel-10 & $5270 \pm 220$ B.P. \\
Tenulampi, sandy mud & Hel-34 & $5190 \pm 160$ B.P. \\
\hline
\end{tabular}

Table 3. Radiocarbon ages dating the peak of the Ladoga transgression before the formation of the River Neva. The ages for Nevskyi Lesopark and Nevskyi Pijatachok are from Malachovskij et al. (submitted).

\begin{tabular}{|c|c|c|}
\hline \multicolumn{3}{|c|}{ Ages older than transgression maximum: } \\
\hline Mantsinsaari, peat below sand & Hel-3402 & $2890 \pm 80$ B.P. \\
\hline \multirow[t]{2}{*}{ Nevskyi Lesopark, peat below sand } & Lu-2404 & $2840 \pm 40$ B.P. \\
\hline & Lu-2405 & $3040 \pm 50$ B.P. \\
\hline \multicolumn{3}{|c|}{ Age younger than transgression maximum: } \\
\hline Nevskyi Pijatachok, peat above sand & Lu-2475 & $2470 \pm 40$ B.P. \\
\hline
\end{tabular}

(Table 2), and, furthermore, two additional datings of the drainage of Lake Saimaa at two sites gave ages around 5200 B.P. Taking all five ages listed in Table 2 into account the age of 5200 B.P. seems appropriate for the formation of the River Vuoksi. Saarnisto's age of about 5000 B.P., however, was the arithmetic mean of 8 dates from 6 sites considered to have stratigraphical changes related to the drainage of Lake Saimaa. The amplitude of these ages is greater than that of the ages in Table 2 (Saarnisto, 1970, p. 61).

When the new outlet of the River Vuoksi was formed at 5200 B.P. the level of Lake Saimaa fell by $2.5 \mathrm{~m}$ (Saarnisto, 1970). Estimating that the Saimaa lake complex during its largest extent, just before the new outlet was formed, was about half of that of Lake Ladoga $\left(17800 \mathrm{~km}^{3}\right)$, Saarnisto concluded that the drainage of Lake Saimaa resulted in a rise of the level of Lake Ladoga of about $1 \mathrm{~m}$. Saarnisto further concluded that the water from the River Vuoksi caused a continuous rise of $1 \mathrm{~m} /$ year in the lake, sufficient to be the main cause of the Ladoga transgression. It may, in any case, be concluded that the added waters of the River Vuoksi at least accelerated the Ladoga transgression (Taavitsainen et al., 1994).

\section{CONCLUSIONS}

The results from the study of the bog Linnansuo in Imatra, together with those earlier presented from the Lake Saimaa area by Saarnisto (1970), date the formation of the River Vuoksi at 5200 B.P. It can be assumed that the waters which drained into Lake Ladoga from Lake Saimaa after its new outlet had opened had an effect on the transgression in Lake Ladoga. The outlet from the north-western corner of Lake Ladoga through the Vetokallio channel near Heinjoki east of Vyborg (Viipuri), but west of Vuoksi (Fig. 1), started to function after the Ancylus transgression at about 9000 B.P. (Delusin, 1991), and ceased to function when the new outlet through the River Neva was established. As many large rivers, such as Svir from Lake Onega and Volchov from the south, in addition to River Vuoksi, flow into Lake Ladoga, it is difficult to estimate the influence of the lastmentioned river on the former water balance of Lake Ladoga and on its Holocene transgression before the formation of the River Neva.

The peak of the Ladoga transgression can be dated by using radiocarbon ages of peats underlying the sands deposited during the transgression and of peats formed on top of the sands after the formation of the River Neva. The peat underneath the beach sand on the island of Mantsinsaari was dated at $2890 \pm 80$ B.P., and similarly the youngest date for a peat below sand in the Nevskyi Lesopark section in the Neva Valley was $2840 \pm 40$ B.P. (Table 3). Further, in the Nevskyi Pijatachok section in the Neva Valley the peat on top of the transgressive sand was dated at $2470 \pm 40$ B.P. These ages date the peak of the Ladoga transgression and the formation of the River Neva to the time interval between about 2900 B.P. and about 2500 B.P. As all radiocarbon ages are based on peat samples, also from the bog Linnansuo in Imatra, they have not been influenced 
by errors frequently encountered in ages of lake sediments. The age of $2900-2500$ B.P. for the formation of the River Neva is somewhat younger than some estimated ages, such as 3100 B.P. quoted by Taavitsainen et al. (1994).

The Holocene Ladoga transgression reached its peak throughout Lake Ladoga at the same time. Before the transgression the outlet was in the north-western part of the lake with a glacioisostatic uplift. This resulted in a tilting of the lake basin towards the south-east. But in addition to this effect it can be assumed that the change to a more humid cool climate after the Holocene climatic optimum, starting at the end of the time of the Sub-boreal chronozone (Table 1), furthered the rise of the water level in Lake Ladoga and eventually led to the formation of its new outlet in the south.

All quoted ages have, as mentioned, been conventional radiocarbon ages. A calibration of them would not essentially alter the ages around 2500 - 3000 B.P., but would increase the age of 5200 B.P. by about 700 years (Stuiver and Pearson, 1993).

ACKNOWLEDGEMENTS: The authors want to thank Tuija Jantunen for drawing the figures, Heikki Haila for help in sampling the sections and all participants in the excursion around Lake Ladoga in 1993 for their help in the field.

\section{REFERENCES}

Ailio, J. (1898). Über Strandbildungen des Litorinameeres auf der Insel Mantsinsaari. Fennia 14 (2), 43 pp.

Ailio, J. (1915). Die geographische Entwicklung des Ladogasees. Fennia 38 (2), 157 pp.

Amantov, A.V. (1993). Stages of Lake Ladoga geological evolution (in Russian). In: Natural environment evolution and the present state of the Lake Ladoga geosystem, ed. N. Davidova and B. Koshechkin. Russian Geographical Association, St Petersburg, 5-13.

Delusin, I. (1991). The Holocene pollen stratigraphy of Lake Ladoga and the vegetational history of its surroundings. Annales Academiae Fennicae A III 153, $66 \mathrm{pp}$.

Donner, J. (1972). Pollen frequencies in the Flandrian sediments of Lake Vakojärvi, south Finland. Societatas Scientiarum Fennica, Commentationes Biologicae 53, $19 \mathrm{pp}$.

Faegri, K. and Iversen, J. (1989). Textbook of pollen analysis, 4th edition. John Wiley \& Sons.

Hellaakoski, A. (1936). Das Alter des Vuoksi. Bulletin de la Commission géologique de Finlande 115, 75-106.

Hyvärinen, H. (1972). Flandrian regional pollen assemblage zones in eastern Finland. Societas Scientiarium Fennica, Commentationes Biologicae 59, $25 \mathrm{pp}$.

Hууррӓ, E. (1943). Beiträge zur Kenntnis der Lagogaund Ancylustransgression. Bulletin de la Commission

géologique de Finlande 128, 139-178.

Koshechkin, B.I. (1990). Geomorphology of the shore zone (in Russian). In: History of the lakes Ladoga, Onega, Pskovo-Chudskoye, Baikal and Khanka, ed. D. Kvasov. Nauka, Leningrad, 49-60.

Koshechkin, B.I. and Ekman, I.M. (1993). Holocene transgression of Lake Ladoga (in Russian). In: Natural environment evolution and the present state of the Lake Ladoga geosystem, ed. N. Davidova and B. Koshechkin. Russian Geographical Association, St. Petersburg, 49-60.

Kvasov, D.D. (1978). The Late-Quaternary history of large lakes and inland seas of Eastern Europe. Annales Academiae Fennicae A III 127, 71 pp.

Kvasov, D.D. (1990). Lake watershed basin alteration (in Russian). In: History of the lakes Onega, PskovskoChudskoye, Baikal and Khanka, ed. D. Kvasov. Nauka, Leningrad, 21-22.

Lappalainen, V. (1962). The shore-line displacement on southern Lake Saimaa. Acta Botanica Fennica 64, 125 pp.

Malachovskij, D.B., Arslanov, K.A., Gej, N.A. and Dginoridze, R.N. (1993). New data on the history of the formation of the River Neva (in Russian). In: Natural environment evolution and the present state of the Lake Ladoga geosystem, ed. N. Davydova and B. Koshechkin. Russian Geographical Association, St. Petersburg, 74-84.

Malachovskij, D.B., Delusin, I.V., Gej, N.A. and 
Dginoridze, R.N. (submitted). Evidence from the Neva Valley of the Holocene history of Lake Ladoga.

Malachovskij, D.B., Gej., N.A., Dginoridze, R.N. and Arslanov, K.A. (1989). To the palaeogeography of the Holocene of the Leningrad area (Nevskij Lesopark section) (in Russian). Vestnik Leningradskogo Universitata, 7 (1), 92-98.

Markov, K.K., Poretskij, V.S. and Shlapina, E.V. (1934). On the oscillations of the level of Lake Ladoga and Lake Onega during Postglacial time (in Russian). Trudi komissii po isutheniju Tchetvertichnogo perioda IV (1), 71-101.

Saarnisto, M. (1970). The Late Weichselian and Flandrian history of the Saimaa Lake Complex. Societas Scientiarium Fennica, Commentationes PhysicoMathematicae 37, 107 pp.

Saarnisto, M. and Siiriäinen, A. (1970). Laatokan transgressioraja (Referat: Die Transgressionsgrenze des Ladogasees). Suomen Museo 1970, 10-22.

Stuiver, M. and Pearson, G.W. (1993). High-precision bidecadal calibration of the radiocarbon time scale, $\mathrm{AD}$ 1950 - 500 BC and 2500 - 6000 BC. Radiocarbon 35 (1), 1-7.

Taavitsainen, J.-P., Ikonen, L. and Saksa, A. (1994). On early agriculture in the archipelago of Lake Ladoga. Fennoscandia archaeologica XI, 29-39. 